parallels the latest current periodicals. He always moved with the times.

Sayce's early interests were mainly of a philological nature, including not only technical work on ancient languages, but also services to the revisers of the Old Testament, and a text and commentary on Herodotus. Later, he turned to questions of comparative religion, and when he was already more than sixty years of age, pure archæology especially attracted him. He acquired. a very complete knowledge of modern work on prehistoric archæology, and the present writer remembers discussing with him, in his eightieth year-and it was Sayce who did most of the discussing - the problems of Mousterian and Upper Palæolithic flints in Transjordan. The geographical and scientific side of Assyriology was always of great interest to him, possibly owing to his early training under the Rev. Bradford Waring Gibson of Trinity College, Cambridge, a keen student of mathematics who was headmaster of Grosvenor College, Bath, where Sayce was educated. Unfortunately, apart from such publications as his "Notes on an Unexplored District of Northern Syria" in the Proceedings of the Society of Biblical Archoeology of 1911, most of his geographical work is buried in former editions of the "Encyclopædia Britannica".

In addition to these wide interests, Sayce was an admirable preacher, and a pleasant and witty companion even to those widely separated from him in years, and it is sad to think that he no longer occupies the rooms in Queen's which he has had since he first became a fellow, nor shall we see any more the frail figure of our old friend walking along the sunny side of the Banbury Road on his way to visit one of his many pupils, for so we were, though he never gave and, indeed, of later years disliked, formal teaching.

Sayce obtained a first-class both in Moderations and Greats, taking his final Schools in 1868, a year which included Andrew Lang, E. A. Knox, afterwards Bishop of Manchester, T. Humphrey Ward, and K. A. Muir-Mackenzie. He obtained his fellowship in 1869, and was classical and theological tutor from 1870 until 1879. He was a member of the Old Testament Revision Company from 1874 until 1884, and deputy professor of comparative philology from 1876 until 1890 ; in the following year he became professor of Assyriology, and resigned in 1914. In 1897 he became president of the Society of Biblical Archæology, and retained this position until the Society was amalgamated with the Royal Asiatic Society in 1918. He was Hibbert lecturer in 1887, Gifford lecturer in 1902, when he discussed "The Conception of the Divine among the Egyptians and Babylonians", Rhind lecturer in 1907 and Huxley lecturer of the Royal Anthropological Institute in 1930. His honours were naturally mainly academic. His old University made him an Hon. D.Litt. in 1907, he was an honorary fellow of the British Academy and Hon. LL.D. of Dublin, and also held the honorary degree of D.D. at Edinburgh and Aberdeen.
It is not possible to recount Sayce's many publications. His first publications were Assyrian grammars; in 1874 he published "Principles of Comparative Philology" and six years later "Introduction to the Science of Language". Perhaps his best-known work is "Fresh Lights from the Monuments" which passed through no less than nine editions between 1883 and 1895, while his standard book on the Old Testament was " "Higher Criticism' and the Verdict of the Monuments" (1894). This does not include a host of other books and articles, some of which have been mentioned above, for, during his long working life, scarcely a year passed without an important contribution from his pen dealing with some aspect of Assyriology.

L. H.D. B.

\section{Mr. T. A. CoWARD}

THE sudden death from heart failure of Thomas Alfred Coward at his home at Bowdon on January 28 leaves a gap in the ranks of British field naturalists and came as a blow to those who knew and loved him.

Coward was born in Bowdon, a Cheshire suburb of Manchester, in January 1867, and there he spent his life. Educated at Brooklands School, Sale, and Owens College, Manchester, he endured nineteen years in the uncongenial atmosphere of a Manchester warehouse, until the absorption by one of the large industrial combines of the firm which he was serving gave him the chance he craved, and for more than thirty years he was able to follow his own bent in studying animals, particularly vertebrates, in the field. He contributed occasional notes and papers to the Proceedings of the Zoological Society, to the Zoologist, British Birds and other more or less technical magazines. Articles in the Field and other newspapers and in the Nineteenth Century appealed to a larger public, and as "T. A. C." of the Manchester Guardian he was widely known.

Of Coward's many books on topography and natural history, the most serious contribution to scientific literature was perhaps the "Vertebrate Fauna of Cheshire and Liverpool Bay" (1912), which ranks high among county faunas, but better known is his "Birds of the British Isles and their Eggs", first issued in 1919, a household word among amateur ornithologists, which has done more to promote and encourage the intelligent study of birds in Great Britain than any other work of our time. To study birds he went to many out of the way parts of Britain from the Shetland Isles to Cornwall, and with his wife, who shared his tastes, visited Holland, the Camargue, the Pyrenees and Hungary in order to find birds he could not see at home.

What Coward wrote was always good reading. It was mostly the outcome of his own wide and varied experience, was free alike from technicalities and rhetorical frippery, and above all was accurate. He had a considerable vogue as a lecturer and his lectures and broadcast talks were compact of the 
same sound material as his writings. For more than a quarter of a century he was a distinctly educative force.

During the War, Coward was acting keeper of the Manchester Museum, and in 1921 the University conferred upon him the degree of M.Sc. in recognition of his services in that capacity. $\mathrm{He}$ was an active member of the Museum Committee, and devoted much time to the arrangement and care of the Dresser collection of birds. He was a member of the executive committee of the Lancashire and Cheshire Fauna Committee, and acted as referee for vertebrates. He was president of the Manchester Literary and Philosophical Society in 1921 and 1922 and a fellow of the Zoological and Entomological Societies.

C. $\mathrm{O}$.

\section{Mr. Henry A. Fleuss}

WE regret to announce the death on January 4 , at the age of eighty-two years, of $\mathrm{Mr}$. Henry Albert Fleuss. He was one of the pioneers of rescue apparatus. After serving in the mercantile service for many years, he left it about 1879 , in order to make a pipeless diving apparatus. He designed a suitable pump for compressing oxygen and made his first test in a tank at the old Polytechnic in Regent St., London. Without any previous experience of diving, he remained under water for one hour, which at that time was an amazing performance.

Fleuss claimed to be the first man to breathe pure oxygen without any ill-effects. At the request of Sir B. W. Richardson, he went into a chamber filled with a gas that meant death in one minute if inhaled, and stayed in there for half an hour. Later, during a lecture given by Sir B. W. Richardson, Fleuss remained in a chamber through which a current of carbon dioxide was made to flow.

Fleuss then turned his attention to mine rescue apparatus and carried out experiments at the Netherseal Colliery and Seaham Colliery. His next exploit was during the building of the Severn Tunnel, the workings of which became flooded. Fleuss went down a shaft $200 \mathrm{ft}$. deep with $40 \mathrm{ft}$. of water at the bottom, and was given up for dead a long time before he returned to the surface. The celebrated diver Lambert then put on the dress and was able to close the necessary doors to enable the tunnel to be pumped out. Messrs. Siebe, Gorman and Co., Ltd., afterwards put the apparatus on the market.

Among Fleuss's other inventions was the wellknown 'Geryk' vacuum pump. He claimed to be the inventor of the first mechanical high efficiency vacuum pump ever made, in 1885 . About $\mathbf{1 8 9 0}$ at a demonstration at the Royal Institution an electric lamp bulb was exhausted with a 'Geryk' pump, and the lamp burned for about 1,000 hours.

Fleuss also invented a tubeless pneumatic tyre which was in great demand about thirty-five years ago.

\section{Dr. Willy Merck}

WE regret to learn from the Chemiker-Zeitung of the death on December 15 of Dr. Willy Merck, a member of the well-known firm of chemical manufacturers, E. Merck of Darmstadt. Dr. Merck, who was born in 1860 at Darmstadt, was the son of Dr. Georg Franz Merck, the discoverer of papaverine. After studying at the Universities of Heidelberg, Strasbourg and Kiel and at the Polytechnic at Aachen, he graduated at Kiel in 1886, where he had worked under the direction of Ladenburg. His thesis embodied the results of his studies on cocaine and he had been able to effect a partial synthesis of this alkaloid by the methylation of benzoylecgonin, a by-product obtained during the extraction of cocaine. Many years later, the complete synthesis of naturally occurring $l$-cocaine and of $d$-pseudococaine was carried out in the Merck laboratories by W. Merck in collaboration with $\mathrm{R}$. Willstätter.

Immediately after his graduation, Merck entered the service of the firm and, after a year's travel in the Far East, he returned to Darmstadt to undertake a leading part in directing the work not only in the laboratories but also in the factory, where he successfully initiated the manufacture of many new drugs. In 1905 the University of Halle conferred upon him an honorary doctorate in the Faculty of Medicine and he was the recipient of many public honours and decorations. He was made Geheimer Kommerzienrat in 1918 on the occasion of the two hundred and fiftieth anniversary of the foundation of the firm.

THE death on February 5 is announced of Mr. J. J. F.-X. King, aged seventy-seven years, one of the best-known Scottish entomologists. Mr. King was an accomplished field naturalist and collector, and some few years ago he presented his main collection of British insects to the University of Glasgow. The University is now to receive under his will the portrait of $\mathrm{Mr}$. King painted by Forrester Wilson and the remainder of his collections, together with his library of books on natural history.

WE regret to announce the following deaths :

Dr. C. A. Barber, C.I.E., lately lecturer in tropical agriculture at the University of Cambridge, formerly Government Botanist, Madras and Sugar Cane Expert for India, on February 24, aged seventy-two years.

Sir Benjamin Gott, chairman of the Commission on Educational and Cultural Films, who was secretary of the Middlesex Education Committee from 1898 until 1928, and formerly headmaster of the Cheltenham School of Science, aged sixtyseven years.

Prof. Johannes Schmidt, director of the Carlsberg Physiological Laboratory, Copenhagen, a leader of several deep-sea expeditions, and known especially for his work on the life-history of the eel, aged fifty-five years. 